\title{
CORPO E SENTIDOS NA SOCIEDADE CONTEMPORÂNEA
}

\author{
Por Maria José Tonelli \\ Professora da FGV-EAESP \\ E-mail: mjtonelli@fgvsp.br
}

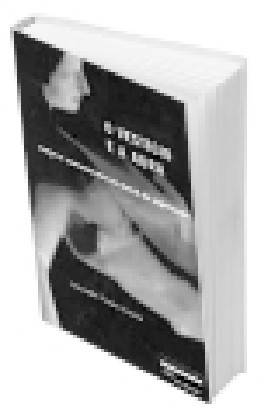

\section{O VESTÍGIO E A AURA: CORPO E CONSUMISMO NA MORAL DO ESPETÁCULO}

De Jurandir Freire Costa

Rio de Janeiro: Garamond Universitária, 2004. 242 p.

Essa mais recente publicação do psicanalista brasileiro Jurandir Freire Costa é uma leitura que exige muito do leitor - independentemente de ser psicólogo - devido a duas questões principais. A primeira é a conhecida erudição do autor, que sabe transitar em várias áreas do conhecimento; a segunda, por tratar, especialmente na primeira parte do livro, de temas estritamente ligados ao universo psicanalítico. Mas vale insistir e vencer a barreira inicial, pois o livro de Freire Costa nos ajuda a compreender o sujeito contemporâneo, a maior contribuição do autor para os leitores do campo da Administração. Afinal, os conflitos, as ambigüidades, os sintomas e todas as dificuldades que 0 autor descreve estão presentes não apenas nos pacientes dos consultórios dos analistas; são questões contemporâ- neas que também fazem parte do espaço organizacional.

A obra é uma análise extremamente aguçada do corpo, do consumismo e do sentido do excesso de objetos que nos rodeiam. A intenção do autor é discutir a sociedade contemporânea e desmistificar al gumas explicações catastróficas e alarmistas sobre a perda de valores e de tradições típicas do O cidente na atualidade. Ele nos mostra que, dentre os sintomas exibidos pelos sujeitos contemporâneos, estão o desconforto em viver, a ansiedade crônica, a apatia, a depressão permanente, as agressões ao próprio corpo e a compulsão consumista. Então a questão de como relacionar esses sintomas com o controle da sexualidade dos tempos freudianos. Os indivíduos contemporâneos são, em geral, sexualmente desinibidos, e fica difícil associar esses sintomas à questão da sexualidade.

De fato, diz o autor, existe uma angústia frente às perdas dos val ores, uma perplexidade que marca nossa conduta que se contrapõem aos ideais de justiça do Iluminismo e aos ideais de auto-real ização do romantismo filosófico e literário. 0 mundo estaria dividido entre esses valores a serem preservados e a moral do espetáculo, em que a imagem do corpo é o centro das atenções. É justamente nesse contexto que o corpo - como sede das sensações e como centro das ações motoras - sofre um desequilíbrio. Os sintomas corporais resultam do conflito entre, de um lado, incorporar emanter a imagem narcísica propagada pela mídia e, de outro, manter o sentimento de continuidade.

Freire Costa argumenta que a nossa cultura é predominantemen- 
te somática, onde a regulação do comportamento social é realizada pelos hábitos de consumo e pelas regras ordenadoras do culto ao corpo. Os indivíduos oscilam entre a crença economicista de que somos aquilo que a produção econômica nos faz crer que somos - crença que está na base de muitas ideologias políticas - e a crença nos sentimentos, na qual somos entes espirituais, que devem ser protegidos do contato com os objetos materiais.

Ao criticar os conceitos freudianos de sexualidade e de pulsão como insuficientes para explicar 0 mal-estar contemporâneo, o autor não chega a indicar o que provocaria o sofrimento do sujeito. Entretanto, descreve os parâmetros que guiam os transtornos atuais, como os distúrbios alimentares, o fisiculturismo compulsivo, a correção cirúrgica e as ansiedades de exposição (síndrome do pânico e fobias sociais). 0 corpo é o centro das atenções, e, justamente por isso, os transtornos deixaram de ser íntimos. A alma e o sujeito psicológico desaparecem, e os transtornos passam a ser do corpo, seja na percepção da imagem, seja nos abusos da exploração das sensações corporais provindos de dependências químicas ou esportes radicais.

0 imaginário da perfeição nos leva a buscar próteses e o corpo é a referência central da imagem ideal do "Eu", especialmente para as elites urbanas. Como afirma Freire Costa, "é verdade que os indivíduos urbanos elegeram o bem-estar e os prazeres físicos como a bússola moral da vida" (p. 132) e na sociedade de espetácuI 0,0 corpo é cel ebrado e não há mais espaço para a vida de sentimentos. Estar feliz hoje significa ter o corpo dos vencedores, da celebridade.

0 autor retoma Winnicott e a sua idéia de que a pulsão é o sentimento da continuidade da existência por meio de ações criativas, mas, na era do espetáculo, a nova felicidade deu as costas para outros prazeres e desequilibrou a economia da afetividade. Por isso, as depressões freqüentes!

Nesse ponto da discussão, 0 autor afirma que o culto ao corpo e a violência são as duas coisas que mais chamam a atenção na vida urbana contemporânea. 0 autor também se apóia em Hannah Arendt para mostrar que o consumismo ocorre pela simultaneidade de dois fenômenos históricos: a fabricação em larga escala de produtos industriais e a invenção filosófica da felicidade. Essas duas condições levaram à incorporação dos objetos como algo que permite a eliminação da insatisfação sentimental. Antes, os objetos se apresentavam como uma expressão da subjetividade, uma forma de externar o íntimo; agora eles constroem a emocionalidade. Richard Sennett, outro autor a ser retomado por Freire Costa, coloca a questão da seguinte forma: o "comprismo" é uma pura prática econômica ou o meio de construção das identidades?

Freire Costa parece demonstrar algum desconforto frente a essa forma de construção da subjetividade, mas mostra o papel importante dos objetos na moral do espetáculo e na construção da privacidade burguesa. Os objetos representam a materialidade necessária à existência. $E$, assim como Gilles Lipovestky, o autor acaba por adotar uma postura em que considera que o sujeito moderno não é um monstro moral, mas preserva os valores fundamentais da ideologia moderna de igualdade, liberdade e democracia. Todavia nos adverte de que esses princípios de justiça e decência são valores frágeis.

Nesse contexto, a violência particularmente forte nos países mais pobres - emerge como uma conseqüência da avidez na busca dos objetos supérfluos, estimulados pela publicidade. 0 aumento da pobreza e a concentração da renda diluíram algumas esferas da vida social, tais como a política, a religião e a tradição familiar, o que levou à desorientação pessoal pela perda dos valores tradicionais, num período de hipertrofia do capitalismo. Entretanto, isso não quer dizer que os valores foram perdidos; eles foram re-hierarquizados de acordo com a ciência e a mitologia científica que guiam alguns dos modismos que condicionam os comportamentos.

Sem dúvida, a leitura da obra de Freire Costa nos faz compreender melhor o nosso tempo, e al guns aspectos tratados por ele poderiam ser complementados com a leitura de outros autores, como Guy Debord em A sociedade do espetáculo, Anthony Giddens em $A$ transformação da intimidade, Zygmunt Bauman em 0 mal-estar na pós-modernidade, Modernidade e holocausto e Modernidade líquida e Thomaz Wood Jr. em Organizações de simbolismo intensivo, que nos ajudam a compreender a diversidade de condutas e a aparente desorientação com que vivemos atualmente.

Contudo, senti falta - talvez fosse essa minha expectativa - de conhecer um pouco mais as especificidades da alma do brasileiro. As descrições do autor colocam a todos dentro de uma modernidade homogeneizante. Será que somos todos iguais? Partilhamos todos do mesmo modo de vida que ele apresenta para as elites urbanas? E não estariam as elites urbanas em transformação? Ainda que a visão apocalíptica não pareça ser a opção de Freire Costa, ao final da leitura 0 mundo não parece cor-de-rosa. 